\title{
Pengaruh Model Brain Based Learning (BBL) Terhadap Hasil Belajar Biologi Siswa Kelas X SMA Negeri Colomadu Tahun Pelajaran 2012/2013
}

\begin{abstract}
The Influence of Brain Based Learning (BBL) Model Toward Biology Learning Achievement of X Degree Students at SMA Negeri Colomadu in 2012/2013 Academic Year
\end{abstract}

\author{
Riska Saparina, Slamet Santosa, Maridi \\ Pendidikan Biologi FKIP Universitas Sebelas Maret \\ Jl. Ir. Sutami 36 A Surakarta \\ Email: riskasaparina@ rocketmail.com
}

Diterima 25 Juli 2013, disetujui 11 September 2013

\begin{abstract}
The aim of this research is to know the influence of brain based learning (BBL) model toward biology learning achievement of $X$ degree students at SMA Negeri Colomadu in academic year 2012/2013.This research was a quasi experiment research using posttest only non equivalent group design. This research applied BBL model in experimental group and deduktif approach with discussion, classical course and questionanswer method in control group. The population of this research was all of $\mathrm{X}$ degree students at SMA Negeri Colomadu in 2011/2012 academic year. Sampling techniques used cluster sampling, that has chosen X4 as experiment group and X5 as control group. Data was collected using multiple choice test, observation sheet, and document. The data were analyzed by t-test. This research concluded that the application of BBL model has taken good effect toward student's achievement cognitive, psychomotor, and affective domain in learning biology of SMA Negeri Colomadu.
\end{abstract}

Key Words: Brain Based Learning Model, Biology Learning Achievement

\section{Pendahuluan}

Pembelajaran sains termasuk di dalamnya biologi merupakan bagian dari pendidikan yang memiliki peranan penting dalam peningkatan mutu pendidikan, khususnya dalam menghasil kan peserta didik yang berkualitas. Pengoptimalkan penguasaan IPA khususnya pada mata pelajaran Biologi, seharusnya tidak sekedar sajian konsep dan informasi tetapi harus menekankan pada pemberian pengalaman langsung untuk mengembangkan kompetensi agar peserta didik menjelajahi dan memahami alam sekitar secara ilmiah, sehingga dapat membantu peserta didik untuk memperoleh pemahaman yang lebih mendalam tentang dirinya sendiri dan alam sekitar. Keberhasilan dalam pembelajaran biologi dapat ditunjukkan dari kualitas peserta didik, salah satunya dapat dilihat dari hasil belajar yang dicapai siswa (Setiawan, 2008). Hasil belajar merupakan kemampuankemampuan yang dimiliki siswa setelah siswa mengalami proses belajar atau pembelajaran. Hasil belajar dalam pendidikan nasional menggunakan klasifikasi hasil belajar Benjamin Bloom yang secara garis besar membaginya menjadi 3 ranah yaitu ranah afektif, 
ranah kognitif dan ranah psikomotorik (Sudjana, 2009:22).

Pencapaian hasil belajar siswa menurut Slameto (2010: 54) dipengaruhi oleh dua faktor, yaitu faktor internal meliputi segala sesuatu yang ada dalam diri siswa, yaitu faktor jasmaniah, faktor psikologis dan faktor kelelahan. Faktor lain yang mempengaruhi belajar siswa adalah faktor eksternal yaitu kondisi di luar diri siswa, meliputi faktor keluarga, faktor sekolah, dan faktor masyarakat. Faktor eksternal, khususnya faktor sekolah berpengaruh langsung terhadap pembelajaran siswa di sekolah, salah satunya adalah faktor model pembelajaran.

Penerapan suatu model pembelajaran yang mampu mengubah minat siswa terhadap pembelajaran biologi ditinjau dari karakteristik pembelajaran biologi yang bersifat abstrak dan teoritis sangat diperlukan. Penerapan model pembelajaran yang variatif dan sesuai dengan karakteristik siswa akan menghindarkan rasa bosan, tercipta suasana belajar yang nyaman dan menyenangkan. Suasana pembelajaran yang menyenangkan hendaknya diusahakan guru dengan memperhatikan otak.

Berdasarkan pemaparan diatas, maka diperlukan suatu model pembelajaran yang mengoptimalkan kerja otak serta diperkirakan dapat meningkatkan hasil belajar siswa. Alternatif model pembelajaran yang dapat meningkatkan hasil belajar siswa serta menciptakan kondisi belajar yang menyenangkan, tanpa beban, dan aktif melibatkan siswa adalah Brain Based Learning (BBL).

BBL merupakan suatu pembelajaran yang diselaraskan dengan cara otak yang di desain secara alamiah untuk belajar, sehingga siswa aktif untuk membangun pengetahuannya yang dilandasi struktur kognitif yang telah dimilikinya serta didasarkan pada cara otak bekerja sehingga diharapkan pembelajaran dapat diserap oleh otak secara maksimal. Given (2007: 58) menyatakan bahwa jika setiap guru dan pengelola sekolah mampu menggunakan BBL, maka akan mengubah kegiatan mengajar secara mendasar, tidak saja menjadi sangat efektif, bahkan hampir seluruh potensi yang dimiliki seseorang akan terbangkitkan.

Ciri pembelajaran BBL adalah kelas yang rileks, pembelajaran yang konstruktivistik, menekankan aspek kerjasama antar siswa, adanya cukup waktu bagi siswa untuk merefleksikan materi yang telah diterimanya, pembelajaran yang bermakna dan kontekstual. Proses belajar mengajar menggunakan BBL cenderung penuh 
kegembiraan, sehingga siswa memiliki motivasi diri. Hal tersebut mendorong kemampuan otak untuk mengintegrasi kan sejumlah informasi yang luas serta melibatkan siswa di dalam suatu proses pembelajaran secara serempak melibatkan akal, kreativitas, dan ilmu psikologi. Model BBL erat kaitannya dengan memberdayakan potensi otak dan kesiapan siswa dalam proses pembelajaran. Slameto (2010: 59) mengungkapkan bahwa kesiapan siswa perlu diperhatikan dalam proses belajar, karena jika siswa belajar dan ada kesiapan, maka hasil belajarnya akan lebih baik. BBL memiliki beberapa tahapan, yaitu tahap pra-pemaparan, persiapan, inisiasi dan akuisisi, elaborasi, inkubasi dan pemasukan memori, verifikasi dan pengecekan keyakinan, serta tahap perayaan. Perlakuan dalam model BBL supaya siswa memperoleh hasil belajar mengajar yang maksimal sesuai dengan kemampuan yang dimiliki (Ardiasih, 2009).

$$
\text { Penelitian bertujuan untuk }
$$
mengetahui pengaruh model BBL terhadap hasil belajar biologi siswa Kelas X SMA Negeri Colomadu. Hasil belajar biologi meliputi hasil belajar ranah kognitif, afektif, dan psikomotor.

\section{Metode Penelitian}

Penelitian ini termasuk kuasi eksperimen dengan pendekatan kuantitatif. Desain penelitian adalah posttest only non equivalent group design dengan menggunakan kelas eksperimen (penerapan model BBL) dan kontrol (pembelajaran ceramah bervariasi).

Populasi dalam penelitian ini adalah seluruh siswa kelas X SMA Negeri Colomadu. Teknik pengambilan sampel dengan cluster sampling, sehingga terpilih kelas $\mathrm{X} 4$ sebagai kelas eksperimen dan kelas X5 sebagai kelas kontrol.

Variabel bebas berupa model BBL dan variabel terikat adalah hasil belajar biologi siswa yang mencakup ranah kognitif, afektif, dan psikomotorik. Teknik pengumpulan data yang digunakan dalam penelitian ini adalah dokumentasi, tes dan observasi. Metode dokumentasi pada penelitian ini berupa dokumen hasil belajar selama satu semester dengan nilai asli sebagai bahan acuannya yang digunakan untuk mengetahui keseimbangan kemampuan awal siswa berdasarkan nilai hasil belajar biologi pada populasi penelitian. Metode tes digunakan untuk mengambil data hasil belajar ranah kognitif. Metode observasi dalam penelitian ini digunakan untuk mengukur hasil belajar ranah 
psikomotorik, ranah afektif dan keterlaksanaan rancangan pembelajaran.

Tes uji coba pada instrumen penelitian dilakukan untuk mengetahui validitas product moment, reliabilitas, daya beda, dan taraf kesukaran. Selain validasi product moment, instrumen juga divalidasi konstruk oleh ahli.

Analisis data pada penelitian dengan menggunakan uji $t$. Sebelumnya dilakukan uji normalitas menggunakan uji Kolmogorov-Smirnov dan uji homogenitas dengan uji Levene's.

\section{Hasil dan Pembahasan}

Hasil analisis pengaruh penerapan model BBL terhadap hasil belajar biologi disajikan pada Tabel 1 berikut:

Tabel 1. Hasil Analisis Pengaruh Model BBL terhadap Hasil Belajar Biologi

\begin{tabular}{|c|c|c|c|c|c|}
\hline Ranah & $\mathrm{t}$ & df & Sig & $\begin{array}{l}t_{(0.05,6} \\
9) \\
\end{array}$ & $\begin{array}{l}\text { Ketera } \\
\text { ngan }\end{array}$ \\
\hline \multirow[t]{2}{*}{ Kognitif } & 4,09 & 6 & 0,00 & 1,995 & sig \\
\hline & 4 & 9 & 0 & & 0,050 \\
\hline \multirow{4}{*}{$\begin{array}{l}\text { Psikomoto } \\
\text { rik } \\
\text { Afektif }\end{array}$} & 4,45 & 6 & 0,00 & 1,995 & sig \\
\hline & 6 & 9 & 0 & & 0,050 \\
\hline & 7,60 & 6 & 0,00 & 1,995 & sig $<$ \\
\hline & 5 & 9 & 0 & & 0,050 \\
\hline
\end{tabular}

Tabel 1 menunjukan bahwa sig. $<0,050$ pada semua ranah hasil belajar sehingga $\mathrm{H}_{0}$ ditolak pada semua ranah, hal ini berarti penerapan model BBL berpengaruh nyata terhadap hasil belajar biologi pada ranah kognitif, afektif dan psikomotorik. Pernyataan tersebut juga didukung secara diskriptif yaitu data nilai rata-rata, nilai minimal, nilai maksimal dan nilai tengah hasil belajar siswa di kelompok eksperimen yang menggunakan BBL dalam pembelajaran lebih tinggi dibandingkan dengan kelompok kontrol yang menggunakan pembelajaran konven sional menggunakan metode ceramah, diskusi dan tanya jawab disertai praktikum.

Hasil tersebut disebabkan karena penerapan BBL pada materi Pencemaran Lingkungan memberikan beberapa hal baru yang tidak terdapat pada pembelajaran yang biasanya dilakukan. Beberapa hal baru dalam BBL tersebut terangkum dalam tujuh sintaks yang meliputi pra-praparan, persiapan, inisisasi dan akuisisi, elaborasi, inkubasi dan memasukkan memori, verifikasi dan pengecekkan keyakinan, serta perayaan (Jensen, 2008: 484). Model BBL akan membuat siswa merasa nyaman, tidak tertekan, aktif terlibat dalam pembelajaran, berani mencoba, tidak takut dalam bertanya dan memusatkan perhatiannya secara penuh pada pembelajaran. Suasana kelas yang membuat siswa merasa nyaman dan membuat siswa aktif sehingga siswa dapat memusatkan perhatiannya secara penuh pada pembelajaran dan hasil belajar meningkat (Saptawulan, 2012:30). 
Model BBL memuat tujuh sintaks yang semuanya terakomodasi dalam penelitian ini. Pembelajaran dengan menerapkan model BBL lebih dapat mengaktifkan siswa dan membuat siswa lebih senang dalam mengikuti pembelajaran. Perlakuan dalam BBL supaya siswa dapat memperoleh hasil belajar mengajar yang maksimal sesuai dengan kemampuan yang dimiliki. Sintaks pertama yaitu pra-paparan, memberikan ulasan singkat tentang pembelajaran baru sebelum benar-benar menggali lebih jauh. Pra-pemaparan membantu siswa untuk membangun peta konseptual yang lebih baik (Jensen, 2008: 484). Semakin banyak latar belakang yang dimiliki siswa menyangkut subjek pembelajaran, semakin cepat meraka akan menyerap dan mengolah informasi baru. Tahap ini guru menyampaikan garis besar materi yang akan dipelajari, sehingga siswa dapat menentukan sasaran materi apa yang akan dipelajarinya.

Sintaks kedua yaitu persiapan adalah tahap bagi guru untuk menciptakan keingintahuan atau kegembiraan. Tahap ini guru menampilkan dua gambar ekosistem yang keadaanya berbeda, sehingga siswa mencari tahu penyebab perbedaan tersebut. Siswa diharapkan termotivasi dan semakin siap untuk melakukan pembelajaran. Slameto (2010: 59) mengungkapkan bahwa kesiapan siswa perlu diperhatikan dalam proses belajar, karena jika siswa belajar dan ada kesiapan, maka hasil belajarnya akan lebih baik. Tahap ketiga adalah inisiasi dan akuisisi, merupakan tahap memberikan pembenaman yang dipenuhi muatan pembelajaran, salah satunya dengan memberikan fakta awal yang penuh ide, rincian, kompleksitas, dan makna. Guru membagi siswa menjadi beberapa kelompok kecil dan membagikan LKS yang bebeda tiap kelompoknya. Guru memunculan isu-isu pencemaran yang terjadi di masyarakat melalui kegiatan observasi lingkungan, dan artikel, sehingga menuntut siswa untuk berpikir kritis dan bertindak ilmiah dalam menanggapi permasalahan di masyarakat tersebut.

Tahap keempat adalah elaborasi. Tahap ini membutuhkan kemampuan berfikir yang murni dari siswa, sehingga menjadikan pembelajaran menjadi bermakna. Fase ini memberikan kesempatan kepada siswa untuk menyortir, menyelidiki, menganalisis, menguji, dan memperdalam pembelajaran. Kegiatan pada tahap ini adalah siswa melakukan praktikum salah satu jenis pencemaran, yaitu pencemaran air, dan menganalisis artikel. Hal ini terjadi karena melalui kegiatan percobaan siswa diberi 
kesempatan untuk memenuhi dorongan rasa ingin tahu dan ingin bisa. Fase ini memberikan kesempatan kepada siswa untuk menyortir, menyelidiki, menganalisis, menguji, dan memperdalam pembelajaran secara mandiri (Jensen, 2008: 58). Hal itu sesuai dengan teori kontruktivisme, sehingga siswa dapat memaknai konsep yang dikonstruk sendiri sehingga pemahaman siswa meningkat. Kelebihan dari fase ini adalah siswa belajar untuk meninjau dan mengevaluasi hasil karya sendiri dan temannya, serta dapat memberikan umpan balik yang membangun dengan cara produktif. Proses elaborasi adalah tahap yang memastikan siswa tidak hanya sekedar mengulang informasi dari fakta yang ada, tetapi juga dapat menghubungkan subjek materi dengan cara yang bermakna. Setiap tahap BBL menjadikan pembelajaran lebih bermakna sesuai teori belajar bermakna David Ausubel. Pembelajaran bermakna merupakan suatu proses mengaitkan informasi baru pada konsep-konsep relevan yang terdapat dalam stuktur kognitif seseorang (Dahar, 2011).

Sintaks kelima adalah inkubasi dan memasukkan memori. Tahap ini menekankan pentingnya waktu istirahat dan waktu mengulang kembali. Otak belajar paling efektif dari waktu ke waktu, bukan langsung pada suatu saat
(Jensen, 2008:488). Tahap ini siswa melakukan refleksi melalui penulisan jurnal pembelajaran. Siswa menuliskan point-point materi yang belum mereka pahami pada materi pembelajaran pada pertemuan hari itu, yakni pencemaran lingkungan. Tahap memasukkan memori didesain dalam bentuk permainan (games) sebelum pembelajaran berakhir. Ismail (2006:8-9) menyatakan bahwa unsur-unsur afeksi, kognisi, dan psikomotor pendukung intelektualitas dapat diaktifkan melalui games, karena permainan merupakan sarana belajar yang paling efektif dan menyenangkan. Metode bermain dapat menjadikan siswa lebih paham tentang apa yang mereka pelajari dan menjadikan suasana lebih menyenangkan (Saptawulan, 2012:30).

Tahapan keenam yaitu verifikasi dan pengecekkan keyakinan. Fase ini pembelajar juga perlu mengkonfirmasi pembelajaran mereka untuk diri sendiri. Konfirmasi tidak hanya dilakukan dengan prsentasi saja, tetapi dapat juga menggunakan metode lain sepert metode mind map. Mind map yang digunakan dalam pembelajaran memberikan dampak positif bagi siswa. Hal tersebut disebabkan mind map membantu mengembangkan kemampuan berpikir serta meningkatkan daya ingat karena informasi disusun secara bercabang dari tema utama dengan menyertakan gambar, 
kombinasi warna, simbol, bentuk. Mind map adalah teknik pemanfaatan keseluruhan otak dengan menggunakan citra visual dan prasarana grafis lainnya untuk membentuk kesan. Teknik ini berdampak kepada siswa menjadi merasa senang sekaligus memfungsikan otak secara optimal, sehingga pembelajarannya dapat membangkitkan minat, bermakna, pemahaman materi, dan memunculkan nilai-nilai yang membahagiakan (Budiman, 2008).

Konfirmasi yang dilakukan oleh siswa kemudian diverifikasi oleh guru untuk menunjang pengetahuan siswa dan membenarkan kesalahan makna yang dibangun oleh siswa, serta kegiatan tanya jawab juga dilakukan oleh guru dengan tujuan agar siswa dapat mengemukakan apa yang kurang paham sehingga dapat dijelaskan kembali oleh guru, selanjutnya siswa diberikan posttest untuk mengetahui sejauh mana kepahaman siswa tentang materi pembelajaran.

Langkah ketujuh adalah tahap Perayaan. Siswa telah mengalami pembelajaran Tahap ini melibatkan emosi, maka pada tahap ini harus dibuat mengasyikan, ceria, dan menyenangkan. Tahap ini menanamkan semua arti penting kecintaan terhadap belajar. Tahap perayaan dilakukan dengan memberikan tepuk tangan, hadiah bagi pemenang atau acungan jempol bagi jawaban yang tepat. Pemberian motivasi dan penghargaan kecil seperti ini dapat membangkitkan persepsi diri yang positif bagi siswa, sehingga hasil belajarnya juga dapat ditingkatkan. Hal ini didukung oleh Hamdu dan Agustina (2011) yang menyatakan bahwa terdapat pengaruh positif yang signifikan antara motivasi terhadap prestasi belajar siswa. Hal ini berarti bahwa siswa yang memiliki motivasi baik dalam belajar, maka prestasi belajarnya juga menjadi lebih baik (tinggi).

\section{Hasil Belajar Ranah Kognitif}

Hasil analisis pengaruh penerapan model BBL terhadap hasil belajar biologi ranah kognitif disajikan pada Tabel 2 berikut:

Tabel 2. Hasil Analisis Pengaruh Model BBL terhadap Hasil Belajar Ranah Kognitif.

\begin{tabular}{lccccc}
\hline Ranah & t & df & Sig & $\mathbf{t}_{(\mathbf{0 . 0 5}, \mathbf{6 9})}$ & Keterangan \\
\hline Kognitif & 4,094 & 69 & 0,000 & 1,995 & sig $<0,050$ \\
\hline
\end{tabular}

Tabel 2 menunjukan sig. $<0,05$ pada ranah kognitif, sehingga $\mathrm{H}_{0}$ ditolak pada ranah kognitif, hal ini berarti penerapan model BBL berpengaruh nyata terhadap hasil belajar biologi pada ranah kognitif.

Nilai rata-rata tes kognitif siswa di kelas eksperimen dengan menggunakan model BBL memperoleh rata-rata 73,716. Nilai tersebut lebih 
tinggi dibandingkan dengan kelompok kontrol yang menggunakan metode ceramah, tanya jawab, dan praktikum dengan nilai rata-rata 65,368 . Hal ini disebabkan karena model BBL yang diterapkan di kelas eksperimen mempermudah siswa dalam mengembangkan kemampuan berpikirnya melalui suasana belajar yang menyenangkan, lebih mengaktifkan siswa, serta berbagai metode yang digunakan, seperti mind map. Mind map yang digunakan dalam pembelajaran memberikan dampak positif bagi siswa. Kecepatan pemahaman konsep sebagai produk dari mind map meningkatkan hasil bejar kognitif siswa, keadaan ini sejalan dengan penelitian Indriani (2008) yang menyatakan bahwa mind mapping dapat meningkatkan hasil belajar siswa.

Kegiatan BBL yang mendukung ranah kognitif yaitu tahap pra-paparan dan persiapan. Tahap ini siswa dibimbing untuk mendapatkan keadaan yang rileks dan nyaman, sehingga siswa memiliki kesiapan untuk belajar. Relevan dengan yang diungkapkan Slameto (2010) bahwa kesiapan siswa dalam proses pembelajaran perlu diperhatikan, karena jika siswa belajar dan memiliki kesiapan, maka hasil belajarnya akan lebih baik. Kegiatan yang mendukung ranah kognitif lainnya yaitu tahap inisiasi dan akuisisi dengan pemunculan isu-isu pencemaran yang terjadi di masyarakat sehingga menuntut siswa untuk berpikir kritis dan bertindak ilmiah dalam menanggapi permasalahan di masyarakat tersebut. Tahap elaborasi dengan kegiatan praktikum yang membutuhkan kemampuan berfikir yang murni dari siswa, sehingga menjadikan pembelajaran menjadi bermakna. Hal ini terjadi karena melalui kegiatan percobaan siswa diberi kesempatan untuk memenuhi dorongan rasa ingin tahu dan ingin bisa. Fase ini memberikan kesempatan kepada siswa untuk menyortir, menyelidiki, menganalisis, menguji, dan memperdalam pembelajaran secara mandiri. Hal itu sesuai dengan teori kontruktivisme, sehingga siswa dapat memaknai konsep yang dikonstruk sendiri sehingga pemahaman siswa meningkat.

Kegiatan praktikum didukung dengan kegiatan diskusi, Kegiatan diskusi kelompok dapat menjadikan siswa membangun konsep secara bersama dalam kelompok yang kooperatif sehingga mereka mampu mengingat materi dengan baik. Pembelajaran melalui diskusi dapat memberikan kesempatan siswa secara intraktif kerjasama dengan temannya dalam mengembangkan pemahaman mereka terhadap konsep-konsep atau prinsip-prinsip penting (Subratha, 2007). Presentasi kelompok dengan tema yang 
berbeda tiap kelompok membuat siswa lebih tertarik, melalui presentasi siswa dapat menjadikan pembelajaran lebih hidup dan terjadi tukar pikiran antar kelompok. Adanya diskusi kelompok dan presentasi mengajak siswa membangun konsep bersama secara kooperatif serta dapat melatih kemampuan berkomunikasi siswa. Siswandi (2006) menyatakan bahwa kemampuan berkomunikasi dapat meningkatkan kemampuan berpikir, bernalar, dan kemampuan memperluas wawasan kemampuan untuk menanggapi persoalan di sekitar siswa. Kesalahan makna juga dapat diminimalisir dengan adanya presentasi. Tahapan inkubasi dan pemasukkan memori tersebut akan memantapkan atau menguatkan konsep siswa tentang materi yang disampaikan sehingga didapatkan hasil belajar yang maksimal. Hal tersebut sejalan dengan hasil penelitian dari Nidhlomuddin (2012) yang menyatakan bahwa penerapan BBL dapat meningkatkan kemampuan kognitif siswa.

Berdasarkan pada semua hal tersebut, jelas bahwa pendekatan BBL memberikan pengaruh positif terhadap hasil belajar biologi ranah kognitif.

\section{Hasil Belajar Ranah Psikomotor}

Hasil analisis pengaruh penerapan model BBL terhadap hasil belajar biologi ranah psikomotor disajikan pada Tabel 3 berikut:

Tabel 3. Hasil Analisis Pengaruh Model BBL terhadap Hasil Belajar Ranah Psikomotor.

\begin{tabular}{cccccc}
\hline Ranah & t & df & Sig & $\mathbf{t}_{(\mathbf{0 . 0 5 , 6 9 )}}$ & Keterangan \\
\hline Psikomotorik & 4,456 & 69 & 0,00 & 1,995 & sig $<0,050$ \\
\hline
\end{tabular}

Tabel 3 menunjukan bahwa sig. $<0,050$ pada semua ranah hasil belajar sehingga $\mathrm{H}_{0}$ ditolak pada ranah psikomotor, hal ini berarti penerapan model BBL berpengaruh nyata terhadap hasil belajar biologi pada ranah psikomotorik.

Ranah psikomotorik adalah ranah hasil belajar yang berkaitan dengan keterampilan (skill) dan kemampuan bertindak individu dari mulai gerakan reflek sampai gerak tubuh (Cartono, 2006). Hasil belajar pada ranah psikomotor berkaitan dengan keterampilan atau kemampuan bertindak setelah siswa menerima pengalaman belajar tertentu. Penilaian hasil belajar ranah psikomotor diperoleh melalui lembar observasi. Hasil uji hipotesis menyatakan bahwa model BBL berpengaruh nyata untuk meningkatkan hasil belajar biologi pada ranah psikomotorik. Nilai rata-rata psikomotor siswa di kelas eksperimen dengan menggunakan BBL memperoleh rata-rata 85,7624. Nilai tersebut lebih tinggi dibandingkan dengan kelompok kontrol 
yang menggunakan metode ceramah, tanya jawab, dan praktikumdengan nilai rata-rata 78,0503 .

Hasil belajar psikomotor ditunjukkan dengan keterampilan manual yang terlihat pada siswa dalam kegiatan fisik. Kelompok kontrol dan kelompok eksperimen sama-sama mendapatkan praktikum dan pengukuran ranah psikomotor diukur dari pelaksanaan praktikum dengan indikator penilaian adalah terampil memilih alat yang digunakan dalam praktikum, terampil melakukan prosedur praktikum, terampil menggunakan mikroskop dalam praktikum identifikasi pencemaran air, dan terampil dalam membuat poster dalam upaya penanggulangan pencemaran lingkungan. Hal tersebut sesuai dengan aspek-aspek keterampilan psikomotor menurut Yulaelawati, 2004. Aspek keterampilan psikomotor tersebut adalah gerakan dasar, dan gerakan fisik. Gerakan dasar merupakan pola gerakan yang diwarisi yang terbentuk berdasarkan campuran gerakan refleks dengan gerakan yang lebih kompleks seperti terampil memilih alat yang digunakan dalam kegiatan praktikum. Kegiatan fisik merupakan kegiatan yang memerlukan kekuatan otot, kekuatan mental, ketahanan, kecerdasan, kegesitan, dan kekuatan suara seperti terampil melakukan prosedur praktikum, menggunakan mikroskop, dan terampil dalam membuat poster.

Kegiatan praktikum dan membuat poster pada tahapan elaborasi dilakukan sebagai aplikasi teori yang diperoleh untuk diterapkan dalam kehidupan guna memecahkan masalah pencemaran di sekitarnya. Pembelajaran biologi yang baik mampu menyajikan konsep-konsep yang dipelajari menjadi contoh yang nyata tentang keadaan atau fenomena pada lingkungan sekitar (Chamany, 2008). Pengembangan keterampilan tersebut penting dalam memberikan pengalaman bagi siswa dalam melakukan praktikum, sehingga dapat mengasosiasikan pengetahuan yang di dapat dengan kehidupan sehari-hari dan pembelajaran menjadi lebih bermakna. Setiap tahap BBL menjadikan pembelajaran lebih bermakna sesuai teori belajar bermakna David Ausubel.

Berdasarkan hasil observasi, siswa pada kelas kontrol secara fisik lebih pasif. Hal tersebut dikarenakan suasana pembelajaran yang kaku dan tidak bervariasi. Pembelajaran BBL memberikan kesempatan bagi siswa untuk mendapatkan pengalaman melalui aktivitas fisik dan melatih penampilan dalam berkomunikasi. Keterlibatan siswa secara fisik berkolaborasi dengan intelektual siswa dalam pembelajaran melatih siswa untuk mampu 
menyelesaikan masalah yang ditemuinya dalam kehidupan dan menjadikan pembelajaran lebih bermakna. Berdasarkan hasil uji hipotesis diketahui bahwa model pembelajaran BBL berpengaruh positif untuk meningkatkan hasil belajar ranah psikomotorik.

\section{Hasil Belajar Ranah Afektif}

Hasil analisis pengaruh penerapan model BBL terhadap hasil belajar biologi ranah afektif disajikan pada Tabel 4 berikut:

Tabel 4. Hasil Analisis Pengaruh Model BBL terhadap Hasil Belajar Ranah Afektif.

\begin{tabular}{cccccc}
\hline Ranah & $\mathbf{t}$ & $\mathbf{d f}$ & Sig & $\mathbf{t}_{(\mathbf{0 . 0 5}, \mathbf{6 9})}$ & Keterangan \\
\hline Afektif & 7,605 & 69 & 0,000 & 1,995 & sig $<0,050$ \\
\hline
\end{tabular}

Tabel 4 menunjukan bahwa sig. $<0,050$ pada ranah afektif, sehingga $\mathrm{H}_{0}$ ditolak pada ranah afektif, hal ini berarti penerapan model BBL berpengaruh nyata terhadap hasil belajar biologi pada afektif.

Ranah afektif berkaitan dengan sikap, nilai-nilai, interes, apresiasi (penghargaan) dan penyesuaian perasaan sosial. Indikator afektif dalam pembelajaran IPA merupakan sikap yang diharapkan saat dan setelah siswa melakukan proses pembelajaran yang berkaitan dengan sikap ilmiah. Rustaman (2005) menyatakan pembelajaran sains tidak hanya menghasilkan produk dan proses, tetapi juga sikap.

Berdasarkan hasil uji hipotesis diketahui bahwa model BBL berpengaruh positif untuk meningkatkan hasil belajar ranah afektif. Nilai rata-rata afektif siswa di kelas eksperimen yang menggunakan model BBL dalam pembelajaran lebih tinggi dibandingkan dengan kelas kontrol yang menggunakan metode ceramah, diskusi dan tanya jawab. Hal ini disebabkan karena model BBL yang diterapkan di kelas eksperimen dalam mendukung siswa untuk meningkatkan karakter dan keterampilan sosial siswa di kelas.

Peningkatan karakter dan keterampilan sosial siswa diperoleh melalui proses diskusi, presentasi, kompetisi antar siswa, penyelesaian tugas maupun penyelesaian tes kognitif yang dilakukan selama proses pembelajaran. Tahap inisiasi dan akuisisi menuntut siswa teliti dalam mengamati lingkungan sekitar, gambar, dan menganalisis artikel, serta dalam pengisian LKS, sehingga menjadikan siswa menjadi lebih jujur dan teliti dalan mengerjakan LKS. Kedisiplin dapat ditingkatkan melalui proses pengumpulan LKS, dan tugas poster. Tahap elaborasi menuntut kerjasama siswa dan kedisiplinan dalam kelompok untuk menanggapi secara aktif masalah yang harus di diskusikan, serta menuntut 
keaktifan siswa untuk mengkomunikasikan hasil diskusinya di depan kelas. Diskusi, penyelesaian tugas dan presentasi pada model BBL mampu meningkatkan sikap disiplin, aktif, dan bekerja sama ketika diskusi.

Pembelajaran dengan diskusi dapat meningkatkan keterampilan sosial. Terkait dengan keterampilan sosial, teori Vygotsky menunjukkan bahwa siswa yang belajar berkelompok mempunyai keterampilan lebih baik dibanding siswa yang belajar sendiri. Kegiatan bekerja sama dalam kelompok menjadikan siswa akan melewati Zone of Proximal Development, yaitu masa dimana siswa lebih optimal dalam menerima informasi ketika berada dalam kerja kelompok. Siswa menerima lebih banyak ide dan informasi dari orang lain yang dijadikan sebagai pengalaman belajar. Teori Vygotsky sesuai dengan pembelajaran BBL, ketika siswa melakukan kegiatan secara aktif dalam diskusi kelompok. Keaktifan dan kerjasama antar siswa ditingkatkan melalui proses diskusi, penyelesaian tugas dan presentasi. Sesuai dengan pernyataan Ba'in (2010) diskusi kelompok dapat meningkatkan keaktifan siswa.

Tahap inkubasi dan memasukkan memori dengan adanya kompetisi antar kelompok dalam permainan dan games juga meningkatkan keaktifan dan kerjasama siswa. Adanya motivasi, afirmasi positif pada saat relaksasi juga membangun karakter positif yang dimiliki siswa. Tahap verifikasi dan pengecekkan keyakinan dalam penerapannya di kelas siswa menjadi lebih jujur dan teliti dalan mengerjakan tes evaluasi.

Berdasarkan hasil uji hipotesis diketahui bahwa model BBL berpengaruh nyata untuk meningkatkan hasil belajar ranah afektif. Nilai rata-rata afektif siswa di kelas eksperimen yang menggunakan model BBL lebih tinggi dibandingkan dengan kelas kontrol yang menggunakan metode ceramah, tanya jawab disertai praktikum. Model BBL yang diterapkan di kelas eksperimen memberikan kesempatan siswa untuk meningkatkan karakter dan keterampilan sosial siswa di kelas melalui penerapan langkah-langkah BBL selama proses pembelajaran. Berdasarkan pernyatan yang telah dipaparkan di atas terlihat bahwa dalam pembelajaran BBL mampu meningkatkan karakter dan keterampilan sosial siswa. Hal tersebut sejalan dengan hasil penelitian Bas (2010) menyatakan bahwa pembelajaran BBL lebih efektif dibandingkan pembelajaran tradisional dalam perkembangan sikap siswa. 


\section{Kesimpulan}

Berdasarkan hasil penelitian dapat disimpulkan bahwa model BBL berpengaruh nyata terhadap hasil belajar biologi siswa kelas X SMA Negeri Colomadu baik pada ranah kognitif, afektif maupun psikomotorik.

\section{Daftar Pustaka}

Ardiasih, R. T. (2009). Eksperimen Pembelajaran Matematika melalui Brain Based Learning pada Pokok Bahasan Matriks ditinjau dari Keaktifan Siswa. Skripsi tidak dipublikasikan, FKIP UMS, Surakarta.

Ba'in, Wijayanti, PS., dan Juariyah, S. (2010). Peningkatan Keaktifan Siswa dalam Pembelajaran Sejarah Kelas XI IA SMA Ibu Kartini Semarang dengan Metode Cooperative Learning. Jurnal Penelitian Pendidikan. 27(1): 92-99.

Bas. (2010). Effects of Brain-Based Learning on Students' Achievement Levels and Attitudes towards English Lesson. Elementary Education Online, 9(2): 488-507.

Budiman, P. (2008). Penerapan Teknik Peta Pikiran untuk Meningkatkan Pemahaman Siswa pada Mata Pelajaran Ilmu Pengetahuan Sosisal Kelas VC SD Santa Ursula BSD, Jurnal Psiko-Edukasi, 6: 34-51.

Cartono, \& Utari, T.S.G. (2006). Penilaian Hasil Belajar. Bandung: Prisma Press Prodaktama

Chamany, K., Allen, D., \& Tanner, K. (2008). Making Biology Learning Relevant to Students: Integrating People, History, and Context into College Biology Teaching, CBE Life Sciences Education, 7, 267-278.

Dahar, R., W. (2011). Teori- teori Belajar dan Pembelajaran. Jakarta: Erlangga
Given, B. K. (2007). Brain-based Teaching. (L. H. Dharma, Penerj.) Bandung: Kaifa.

Hamdu, G dan Agustina, L. (2011). April. Pengaruh Motivasi Belajar Terhadap Prestasi Belajar IPA di Sekolah Dasar. Jurnal penelitian Pendidikan. 12 (1). 90-96.

Indriani, N. (2008). Meningkatkan Keterampilan Kreativitas Belajar Siswa dalam Mata Pelajaran IPS dengan Menggunakan Mind Mapping pada Kelas IX-1 SMPN 5 Padang Panjang, Jurnal Guru 5(1): 7-16

Ismail, A. (2006). Education Games menjadi Cerdas dan Ceria dengan Permainan Edukatif. Yogyakarta: Pilar Media.

Jensen, E. (2008). Brain-Based Learning (Edisi Revisi). (N. Yusron, Penerj.) Yogyakarta: Pustaka Pelajar.

Nidhlomuddin, A. N. (2012). The Implementation of Brain Based Learning to Improve Student Learning Outcomes in The Matter of Salt Hydrolysis in Class XI SMAN 1 Cerme Gresik. 1 (1), 1-9.

Rustaman, N Y. (2005). Strategi Belajar Mengajar Biologi. Bandung: UPI \& JICA IMSTEP.

Saptawulan, A. (2012). Belajar Biologi yang Menyenangkan dengan Permainan Kuartet dan Pementapan Konsep secara Mandiri melalui Blog. Jurnal Pendidikan Penabur, 18, 2835.

Setiawan, I. G. (2008). Penerapan Pengajaran Kontekstual Berbasis Masalah untuk Meningkatkan Hasil Belajar Biologi Siswa Kelas X2 SMA Laboratorium Singaraja. Jurnal Penelitian dan Pengembangan Pendidikan, 2 (1), 42-59.

Siswandi, H.J. (2006). Meningkatkan Keterampilan Berkomunikasi Melalui Metode Diskusi Panel dalam Mata Pelajaran Bahasa Indonesia di Sekolah Dasar (Penelitian Tindakan Kelas). Jurnal Pendidikan Penabur, 7: 24-35. 
Slameto. (2010). Belajar dan FaktorFaktor yang Mempengaruhinya. Jakarta: Rineka Cipta.

Sudjana, N. (2009). Penilaian Hasil Proses Belajar Mengajar. Bandung: Remaja Rosdakarya.

Subratha, N. (2007). Pengembangan Model Pembelajaran Kooperatif dan Strategi Pemecahan Masalah untuk
Meningkatkan Hasil Belajar Siswa Kelas VII C SMA Negeri 1 Sukasada. Jurnal Penelitian dan Pengembangan, 1 (2), 135-147.

Yulaelawati, E. (2004). Kurikulum dan Pembelajaran. Bandung: Pakar Karya. 